\title{
Environmental groups get Supreme Court boost on endangered species
}

Washington. In an increasingly rare victory for environmental advocates, the US Supreme Court last week ruled that destroying wildlife habitat constitutes a type of harm to protected species, and can therefore be prohibited by law.

The 6:3 decision overturns a lower court ruling that the Endangered Species Act (ESA) forbids only direct, intentional harm to animals and plants, a ruling that would have negated federal regulations that are intended to prevent private property owners from destroying habitat.

The justices looked to Webster's Third New International Dictionary, among other sources, to help make their decision, which focused on the fate of the northern spotted owl in Oregon. Writing for the majority, Justice John Paul Stevens held that the dictionary definition of the verb form of 'harm' is "to cause hurt or damage to; injure". In the context of the act, he said, that definition "naturally encompasses habitat modification that results in actual injury or death to members of an endangered or threatened species".

The decision, known as Babbitt vs Sweet Home Chapter of Communities for a Great Oregon, confirms - perhaps for good the legal basis of the ESA, which comes before Congress for reauthorization this year. It follows on the heels of a strong

\section{IMAGE \\ UNAVAILABLE FOR COPYRIGHT REASONS}

Sitting comfortably: habitat of the northern spotted owl now has judicial protection.

scientific endorsement of the act by the National Academy of Sciences in May (see Nature, 375, 349; 1995).

Yet environmentalists were hardly in a mood to celebrate. Two days earlier, the House of Representatives Appropriations Committee had voted to slash the budgets of

\section{'All lines from space are engaged...'}

London. The ubiquitous mobile telephone is threatening the future of radioastronomy, according to the European Science Foundation's Committee on Radio Astronomy Frequencies (CRAF).

Five major telecommunications companies are believed to be putting pressure on the International Telecommunications Union (ITU) in Geneva to delete a crucial phrase in the Radio Regulations that protects radioastronomers from interference on shared and adjacent frequency bands, according to CRAF's chairman-designate, James Cohen.

Radioastronomers share the 1610.61613.8 MHz frequency band with mobile satellite systems. A footnote forbidding "harmful interference" was inserted into the regulations at the request of British radioastronomers in 1992. But telecommunications organizations continue to disregard the clause, and five companies are now believed to have written to the US Federal Communications Commission asking for the footnote to be erased.

"Interference from radio and cell-phone activity is a growing problem, which the ITU appears reluctant to recognise," says Cohen, co-author of a technical Handbook on Radio Astronomy published by CRAF later this month. "We face an uphill struggle."

Meanwhile the radioastronomy community, which occupies a minority position on the ITU, the United Nations agency that governs worldwide frequency allocations, is facing a new threat.

Telecommunications groups will ask the ITU at its next meeting in November to approve a network of low-Earth orbiting satellites to meet the growth in mobile communications.

The satellites will need access to several frequency bands that are crucial to radioastronomy. If the proposals are accepted, "up to half of all current radioastronomy activity is at risk," says Cohen.

Cable and Wireless, the global telecommunications group with interests in 25 countries, declined to comment on CRAF's charges. A spokesman added that no statement would be made until after the ITU meeting.

Ehsan Masood the two federal agencies responsible for biological research within the Department of Interior, which administers the ESA.

The committee deleted all money (about $\$ 12.5$ million) in the Fish and Wildlife Service's 1996 budget for listing or 'pre-listing' new threatened or endangered species. Such listings are already under a moratorium imposed by Congress - deleting next year's funding would simply extend the moratorium and stop the ESA in its tracks.

The committee also effectively abolished the new National Biological Service (NBS) by transferring its functions to the US Geological Survey (USGS) and cutting its budget by one third, to $\$ 113$ million. The beleaguered director of NBS, Ron Pulliam, released a statement calling the vote a "decision to throw the baby out with the bath water", and saying that the merger of NBS with the USGS "reflects a misunderstanding of the basic responsibilities of the two agencies".

In a more-than-usually pointed message, Pulliam repeated an argument he has made unsuccessfully in the Congress, namely that research by the biological survey serves not only the scientific community, but also industry and business, private landowners, developers, and the American public in general. "Contrary to the charges made by some 'fearmongers' on the Hill, NBS is non-advocacy and does not participate in regulatory decisions," he wrote.

But property rights advocates in Congress continue to make NBS a special target. The House committee added a provision to the appropriations bill that appears to prohibit agency scientists from conducting research on private land, even with the permission of the property owner.

Furthermore, a prohibition against the use of volunteer labour appears to have been extended to the use of data produced by volunteers. This would prevent the agency from using, for example, bird census data collected by the National Audubon Society and other similar groups.

If the budget cuts and restrictions survive the passage through the full House and Senate, they would "devastate the biological science capabilities of the Department of the Interior", said Pulliam. But all he can do now is hope for a saviour elsewhere in the House - or more likely in the Senate.

Time is running short. The full House is scheduled to take up the appropriations bill within the next two weeks, at the same time as Don Young (Republican, Alaska), an avowed ESA-hater, is planning to introduce his rewritten version of the Endangered Species Act. Tony Reichhardt 